\title{
NEGARA HUKUM DAN DEMOKRASI PANCASILA DALAM KAITANNYA DENGAN HAK ASASI MANUSIA (HAM)
}

\author{
Bobi Aswandi', Kholis Roisah ${ }^{2}$ \\ Program Studi Magister IImu Hukum \\ Fakultas Hukum Universitas Diponegoro \\ J alan Imam Bardjo, S.H. No. 1-3, Kampus Pleburan, Semarang 50241 \\ bobi.aswandi1992@gmail.com \\ ABSTRACT
}

\begin{abstract}
Human rights are basic rights or basic rights brought by humans from birth which are inherently inherent in every human being and cannot be contested because it is a gift from God Almighty, Indonesia as a democratic state of Pancasila law has obligations in the protection of human rights, protection of Human Rights in a state of law must be included in the constitution or national law. The type of research used in this study is normative juridical research. As a state of Pancasila law, Human Rights have been contained in the Pancasila itself, such as freedom in religion and belief. Whereas as a Pancasila democracy, the protection of human rights is both a goal and a precondition for the passage of democracy.
\end{abstract}

\section{Keywords: State Law, Democracy ; Human Rights.}

\begin{abstract}
ABSTRAK
Hak Asasi Manusia adalah hak pokok atau hak dasar yang dibawa oleh manusia sejak lahir yang secara kodrat melekat pada setiap manusia dan tidak dapat di ganggu gugat karena merupakan anugerah Tuhan Yang Maha Esa, Indonesia sebagai negara hukum pancasila yang demokratis memiliki kewajiban dalam perlindungan hak asasi manusia, perlindungan HAM dalam negara hukum harus termaktub dalam konstitusi ataupun hukum nasional. Jenis penelitian yang digunakan dalam penelitian ini ialah penelitian yuridis normatif. Sebagai negera hukum pancasila HAM telah termuat dalam pancasila itu sendiri, seperti kebebasan dalam beragama dan kepercayaan. Sedangkan sebagai negara demokrasi pancasila, perlindungan HAM menjadi tujuan sekaligus prasyarat bagi berjalannya demokrasi.
\end{abstract}

Kata Kunci: Negara Hukum, Demokrasi; HAM.

\footnotetext{
${ }^{1}$ Mahasiswa Program Studi Magister Ilmu Hukum Universitas Diponegoro

2 Dosen Program Studi Magister Ilmu Hukum Universitas Diponegoro
} 


\section{A. Pendahuluan}

\section{Latar Belakang}

Doktrin tentang HAM sekarang ini sudah diterima secara universal sebagai a moral, political, and legal framework and as a guideline dalam membangunan dunia yang lebih damai dan bebas dari ketakutan dan penindasan serta perlakuan yang tidak adil. Oleh karena itu, dalam paham negara hukum, jaminan perlindungan HAM dianggap sebagai ciri yang mutlak harus ada di setiap negara yang dapat disebut rechsstaat (Assiddiqie, 2012). Dalam konteks negara hukum, melalui UndangUndang Dasar Republik Indonesia 1945, politik hukum nasional telah menetapkan bahwa Indonesia adalah negara hukum, sebagaimana diatur dalam Pasal 1 ayat (1) Undang-Undang Dasar Republik Indonesia Tahun 1945 (Marbun: 2014). Sebagai konsekuensi Indonesia adalah negara hukum sebagai mana termaktub didalam Undang-Undang Dasar Republik Indonesia Tahun 1945 tersebut, maka usaha untuk mempertahankan dan melindungi HAM itu adalah menjadikan HAM tersebut sebagai bagian dari hukum nasional (Yuliartha, 2009).

Secara harfiah, Hak Asasi Manusia adalah hak pokok atau hak dasar yang dibawa oleh manusia sejak lahir yang secara kodrat melekat pada setiap manusia dan tidak dapat di ganggu gugat karena merupakan anugerah Tuhan Yang Maha Esa, atau dapat dikatakan HAM merupakan penghargaan terhadap derajat dan martabat manusia yang merupakan pengakuan yang nyata bahwa manusia adalah manusia (Hamidi, dkk, 2012). Dalam perkembangan selanjutnya, jaminan HAM itu juga diharuskan tercantum dengan tegas dalam UndangUndang Dasar atau konstitusi tertulis negara demokrasi konstitusional (constitutional democracy), dan dianggap sebagai materi terpenting yang harus ada dalam konstitusi, disamping materi ketentuan lainnya seperti menegani format kelembagaan dan pembagian kekuasaan negara dan mekanisme hubungan antarlembaga negara (Assiddiqie, 2012).

Bagi Indonesia, penegakan HAM merupakan prinsip yang selalu dipegang teguh. Sebagai bangsa yang pernah mengalami penjajahan maka pendiri republik kita ini sadar akan arti HAM dalam kegiatan bernegara. Hal ini terlihat dari penempatan prinsipprinsip serta hak-hak yang paling fundamental ini di dalam Undang-Undang Dasar Republik Indonesia Tahun 1945 yang justru lahir lebih dahulu dari Universal Declaration of Human Right. Disamping itu, gagasan negara hukum yang demokratis tempat di mana hak asasi manusia (HAM) diakui, dihormati dan dilindungi telah dikemukakan oleh para perintis kemerdekaan Republik Indonesia. Gagasan dan Konsep Negara Hukum dan Demokrasi tempat di mana HAM dimajukan dan dilindungi terus hidup dan membara dipikiran dan hati para pendiri bangsa. Hal itu nampak nyata pada penyusunan konstitusikonstitusi yang berlaku di Indonesia.

Demokrasi adalah cara pelaksanaan negara sebagai organisasi kekuasaan yang menjamin pengakuan terhadap HAM dan pelaksaan demokrasi juga harus dilandasi oleh HAM, oleh sebab itu, memahami demokrasi secara komprehensif maka 
didalamnya juga harus memahami HAM, demikian juga sebaliknya (Neta, 2011). Demokrasi dan HAM sejatinya bukan isu baru. hampir seluruh negara di dunia saat ini menyatakan diri sebagai negara yang demokratis dan menghormati HAM. Demokrasi menempatkan manusia sebagai pemilik kedaulatan yang kemudian dikenal dengan prinsip kedaulatan rakyat. Berdasarkan pada teori kontrak sosial, untuk memenuhi hak-hak setiap manusia tidak mungkin dicapai oleh masing-masing orang secara individual, tetapi harus bersama-sama (Asshiddiqie, 2012).

Penelitian dan ataupun penulisan artikel maupun jurnal mengenai Negara Hukum, Demokrasi dan Hak Asasi Manusia sebelumnya juga telah dilakukan oleh Fauzan Khairazi dengan judul Implementasi Demokrasi dan Hak Asasi Manusia di Indonesia, dalam penelitiannya Fauzan Khairazi memfokuskan pada dua pembahasan pokok, yaitu: Pertama, konsep negara hukum pada umumnya seperti konsep negara hukum eropa continental (rechsstaat) dan anglo amerika (the rule of law). Kedua, konsep ideal demokratisasi dan kebebasan warga negaga ditinjau dari aspek konseptual hukum tata negara ke depan. Sedangkan dalam penulisan artikel ini, penulisan juga d fokuskan pada dua pembahasan pokok namun berbeda dengan penelitian sebelumnya, perbedaan tersebut yaitu: Pertama, penulisan ini memfokuskan bagaimana keterkaitan negara hukum dan hak asasi manusia, namun bukan negara hukum eropa continental (rechsstaat) maupun anglo amerika (the rule of law), melainkan negara hukum Pancasila. Kedua, penulisan ini difokuskan pada konsep negara demokrasi pancasila dan kaitannya dengan HAM di Indonesia, dan tidak berbicara bagaimana konsep HAM yang ideal dalam negara domokrasi maupun hukum tata negara ke masa yang akan datang.

Lebih lanjut, banyak negara yang mengakui diri mereka sebagai negara hukum dan demokratis, namun masih metutup mata akan pelanggaran Hak Asasi Manusia, contoh saja Amerika Serikat. Sebagaimana dikutip dari detiknews.com, Organisasi HAM terkemuka Human Rights Watch (HRW) merilis laporan yang mengkritik keras Amerika Serikat atas pelanggaran HAM diberbagai bidang. Menurut laporan HRW, hukum dan praktik-praktik Amerika Serikat melanggar HAM yang diakui secara internasional, misalnya dalam hal penahanan, pengadilan kejahatan, perbedaan rasial, pembunuhan yang dilakukan polisi terhadap warga Amerika berkulit hitam dan kebijakan luar negeri. (Hutapea, 2016).

Amerika Serikat menahan hingga 2,37 juta orang, penduduk terbesar di dunia yang dilaporkan dipenjara," demikian laporan HRW seperti dilansir media Press TV, Selasa (2/1/2016). Disebutkan HRW, hingga kini 31 negara bagian AS masih menerapkan hukuman mati, dengan tujuh negara bagian di antaranya melakukan eksekusi-eksekusi pada tahun 2014. Juga sebanyak 27 orang telah dieksekusi dengan disuntik mati di Amerika Serikat sepanjang tahun 2015.

Mengenai perbedaan rasial dalam pengadilan kejahatan, laporan HRW menunjukkan 
bahwa "ketika warga Amerika Afrika dan kulit putih terlibat pelanggaran narkoba dengan tingkat yang sama, maka warga Amerika Afrika ditangkap, diadili dan ditahan atas dakwaan narkoba dengan jumlah yang jauh lebih tinggi. Meskipun warga kulit hitam hanya mencapai 13 persen dari seluruh populasi AS, tercatat ada 29 persen penangkapan karena narkoba dikalangan mereka. Dalam laporan HRW disebutkan, warga kulit hitam yang ditahan jumlahnya enam kali lebih besar daripada warga kulit putih. Laporan HRW juga menyoroti pembunuhan warga kulit hitam oleh polisi-polisi Amerika Serikat.

Selanjutnya, berdasarkan analisis global, Maplecroft, dalam atlas resiko HAM 2014 (Human Risk Atlas/ HRRA) mengungkapkan bahwa jumlah negara dengan "resiko ekstrem" pelanggaran HAM telah meningkat secara dramatis. Indonesia berada di urutan ke-30 dalam peringkat negara dengan kondisi HAM terburuk (Tribun Jogja.com, 2013).

Supremasi hukum dan hak asasi manusia (HAM) tampaknya masih menjadi pekerjaan rumah terberat yang harus diselesaikan Indonesia sejak republik ini berdiri pada 17 Agustus 1945. Menilik 20 tahun kebelakang saja, terdapat sejumlah catatan hitam dalam ranah hukum dan HAM. Amanah gerakan reformasi 1998 terkait supremasi hukum belum juga terwujud.

Beberapa pelanggaran HAM di Indonesia terjadi sejak reformasi bergulir pada tahun 1998, diantaranya yaitu: Pertama, Tragedi Trisakti yang menewaskan empat mahasiswa trisakti, Kedua, Tragedi Semanggi 1 dan 2 yang menyebabkan 11 orang meninggal akibat penembakan oleh aparat keamanan, Ketiga, Konflik Maluku 19 Januari 1999 yang berakar dari ketidak puasan sebagian masyarakat atas kondisi sosial politik yang kemudian menyertakan sentiment perbedaan agama, pada 6 Februari 2001, Komisi Penyelidik Pelanggaran HAM dan Mediasi (KPMM) di Maluku mencatat, sejak januari 1999 hingga oktober 2000 setidaknya 3.080 tewas, 4.024 luka-luka, dan 281.365 orang lainnya mengungsi. Keempat, Konflik Poso sepanjang tahun 1998-2001, merupakan konflik antara kelompok Kristen dan dan Muslim dengan prediksi korban sampai 1000 orang. Kelima, Konflik Sampit 18 febriari 2001, merupakan konflik abtar suku dayak dan Madura sebagai pendatang, antropolog Belanda Gerry van Klinken memprediksi korban tewas mencapai 500-1000 orang dan lebih dari 25.000 orang mengungis. Keenam, pelanggaran kebebasan beragama di bali pada tahun 2008 yang di kenal dengan kasus Mushala Asy-Syafiiyah. Ketujuh, Pengusiran ribuan anggota Kelompok Gerakan Fajar Nusantara (Gafatar), Kedelapan, Kasus deskriminasi pembangunan gereja di Aceh Singkil, Kesembilan, Kasus HKPB Filadelfia di Bekasi, Kasus gereja Yasmin di Bogor. Kesepuluh, kekerasan terhadap Jemaah Ahamadiyah, dalam kurun waktu 2016-2017 terdapat 11 kasus penutupan masjid Ahmadiyah. Sebagian besar penutupan masjid justru diinisiasi oleh pemerintah daerah dan perusakan terhadap property milik Jemaah Ahmadiyah di Lombok Timur pada Mei 2018. dan Kesebelas, Kerusuhan Tolikara pada tahun 2015, peristiwa ini terjadi ketika massa 
Gereja Injli di Indonesia (GIDI) berusaha membubarkan jamaah Muslim yang tengah menjalankan sholat Idul Fitri. (Erdianto, 2018).

Melihat masih banyaknya bentuk pelanggaran HAM yang terjadi di Indonesia, maka peneliti ingin melakukan penelitian untuk mengetahui bagaimana konsepsi negara hukum dan demokrasi pancasila dalam kaitannya dengan Hak Asasi Manusia.

Berdasarkan uraian pada latar belakang diatas, maka penulisan artikel ini berjudul "NEGARA HUKUM DAN DEMOKRASI PANCASILA DALAM KAITANNYA DENGAN HAK ASASI MANUSIA (HAM)".

\section{Perumusan Masalah}

Penelitian ini ingin mencari jawaban atas pertanyaan penelitian sebagai berikut:

1. Bagaimana Konsepsi Negara Hukum Pancasila dalam Kaitannya dengan Hak Asasi Manusia?

2. Bagaimana Konsepsi Negara Demokrasi Pancasila dalam kaitannya dengan Hak Asasi Manusia?

\section{B. METODE PENELITIAN}

Dalam penelitian ini menggunakan metode pendekatan yuridis normatif / doktrinal, sehingga data yang diperlukan meliputi data sekunder yang dilakukan dengan studi pustaka atau "literature study" . Sedangkan metode analisa data yang dipergunakan bersifat Analisis Kualitatif Normatif.
Penelitian ini bersifat kualitatif karena mengandalkan kedalaman data dengan metode deskriptif-analitis (Rahayu, 2018).

\section{c. PEMBAHASAN}

1. Konsepsi Negara Hukum Pancasila dalam Kaitannya dengan HAM

Konsep negara hukum yang dianut dalam Undang-Undang Dasar Republik Indonesia Tahun 1945 adalah negara hukum yang aktif dan dinamis. Model negara hukum seperti ini menjadikan sebagai pihak yang aktif berorientasi pada pemenuhan dan perwujudan kesejahteraan rakyat sesuai dengan prinsip welvaarstaat (Ridlwan, 2012).

Sebagai negara hukum, segala tindakan penyelenggara negara dan warga negara harus sesuai dengan aturan hukum yang berlaku. Hukum dalam hal ini adalah hierarki tatanan norma yang berpuncak pada konstitusi, yaitu Undang-Undang Dasar Negara Republik Indonesia Tahun 1945. Disamping itu, hukum yang diterapkan dan ditegakkan harus mencerminkan kehendak rakyat, sehingga harus menjamin adanya peran serta warga negara dalam proses pengambilan keputusan kenegaraan. Hukum tidak dibuat untuk menjamin kepentingan kepentingan beberapa orang yang berkuasa, melainkan untuk menjamin kepentingan segenap warga negara (Gaffar, 2012).

Hans Kelsen memberikan argumentasi bahwa dalam kaitan negara hukum yang juga merupakan negara demokratis setidak-tidaknya harus memiliki 4 (empat) syarat rechtsstaat. Pertama, negara yang kehidupannya sejalan dengan konstitusi 
dan Undang-Undang; kedua, negara yang mengatur mekanisme pertanggung jawaban atas setiap kebijakan dan tindakan yang dilakukan oleh penguasa; ketiga, negara yang menjamin kemerdekaan kekuasaan kehakiman serta adanya peradilan administrasi negara; dan keempat, negara yang memilindungi hak asasi manusia (Simamora, 2014). Dari argumen yang diberikan oleh Hans Kelsen tersebut dapat di simpulkan bahwa konsep hak asasi manusia tidak dapat dipisahkan dengan keberadaan Negara hukum yang tentunya mengedepankan dan melindungi hak asasi manusia. Oleh karena itu berbicara Negara hukum tentunya tidaklah mungkin terlewatkan pembahasan tentang HAM.

Jika berdasarkan Undang-Undang Nomor 39 Tahun 1999 tentang Hak Asasi Manusia, Pasal 1 ayat (1) dinyatakan bahwa:

hak asasi manusia adalah seperangkat hak yang melekat pada hakikat dan keberadaan manusia sebagai makhluk Tuhan Yang Maha Esa dan merupakan anugerah-Nya yang wajib dihormati, dijunjung tinggi, dan dilindungi oleh negara hukum, pemerintahan, dan setiap orang demi kehormatan serta perlindungan harkat dan martabat manusia.

Prinsip pengakuan dan perlindungan terhadap hak-hak asasi manusia, merupakan bagian dari prinsip perlindungan hukum. Istilah hak asasi manusia di Indonesia, sering disejajarkan dengan istilah hak-hak kodrat, hak-hak dasar manusia. natural rights, human rights, fundamental rights, gronrechten, mensenrechten, rechten van den mens dan fundamental rechten Menurut Philipus M Hadjon, di dalam hak (rights), terkandung adanya suatu tuntutan (claim) (Khairazi, 2015).

Pilihan kebijakan hukum (legal policy) bahwa Indonesia adalah merupakan negara hukum telah dianut selama 60 tahun. Sebagai konsekuensi, terlepas dari konsep acuan yang dianut, apakah konsep Rechtsstaat dari tradisi Eropa Kontinental (Civil Law), atau konsep Rule of Law tradisi Anglo Saxon (Common Law), masalah penegakan supremasi hukum dan penghormatan (Respect), perlindungan (protect), serta pemenuhan (fulfill), hak asasi manusia (HAM) haruslah menjadi pilar utama penyelenggaraan negara, disamping adanya pembagian kekuasaan dalam mekanisme checks and balances dengan dijaminnya independensi yudisial (Soehino, 2011).

Indonesia adalah negara hukum termuat dalam Pasal 1 ayat (3) Undang-Undang Dasar Republik Indonesia Tahun 1945. Tahir Azhari (1995:19), mengemukakan bahwa meskipun dalam penjelasan Undang-Undang Dasar Republik Indonesia Tahun 1945 digunakan istilah rechtsstaat, namun yang dianut oleh negara Indonesia bukanlah konsep rechtsstaat maupun rule of law (Qamar, 2010). Alasannya, Konsep negara hukum sebenarnya bukanlah konsep yang lahir dari kebudayaan Indonesia melainkan dari dunia barat, sebagaimana diutarakan oleh Satjipto Rahardjo yang di kutip oleh Yance Arizona yang menyatakan bahwa:

"negara hukum adalah konsep modern yang tidak tumbuh dari dalam masyarakat Indonesia sendiri, tetapi barang import. Proses menjadi negara hukum bukanlah merupakan bagian dari sejaarah 
sosial-politik bangsa Indonesia di masa lalu, seperti terjadi di Eropa. Negara hukum merupakan bangunan yang dipaksakan dari luar (imposed from outside). Dengan demikian, membangun negara hukum adalah membangun perilaku bernegara hukum, membangun suatu peradaban baru (Wijaya, 2015).

Rahardjo (2009) dalam bukunya Negara Hukum Yang Membahagiakan Rakyatnya berpendapat bahwa negara bukan hanya merupakan bangunan hukum, politik dan sosial, melainkan juga kultural. Oleh sebab itu, kita boleh mengamati watakwatak kultural suatu negara. Disisi lain, suatu negara hukum juga "dituntut" untuk menampilkan wajah kulturalnya. Indonesia memiliki sebuah pandangan sebagai negara hukum dengan karakteristik yang khas, yaitu negara hukum Pancasila. Dalam hal ini, merujuk pada pendapat Arief Hidayat (2011), pada pembukaan dan Pasal-Pasal dalam Undang-Undang Dasar Republik Indonesia Tahun 1945, konsep yang dianut negara hukum Indonesia sejak diproklamasikan kemerdekaan hingga sekararang bukanlah konsep rechtsstaat dan bukan pula konsep the rule of law. Akan tetapi membentuk suatu konsep negara hukum baru, yang bersumber pada pandangan dan falsafah hidup luhur bangsa Indonesia, yaitu negara hukum pancasila (Kiemas, 2013). Dimana negara hukum pancasila merupakan negara hukum yang berasaskan kepada nilai-nilai pancasila.

Menurut M. Tahir Azharry, menyebutkan salah satu ciri dari negara hukum pancasila ialah adanya asas negara kekeluargaan (Wijaya, 2015).
Dalam suatu negara keleuargaan terdapat pengakuaan terhadap hak-hak individual (termasuk pula hak milik ataupun hak asasi tetapi dengan tetap mengutamakan kepentingan nasional (kepentingan bersama) diatas kepentingan individu. Disamping karakter, konsep negara hukum pancasila juga memiliki beberapa prinsip yang salah satunya, adanya perlindungan HAM dengan jaminan hukum bagi tuntutan penegakannya melalui proses yang adil. Perlindungan terhadap HAM ini dimasyarakatkan secara luas untuk mempromosikan penghormatan perlindungan terhadap HAM sebagi ciri yang penting suatu negara hukum yang demokratis (Kiemas, 2013).

Menurut Oemar Seno Adji yang dikutip dari Wijaya (2015) menyebutkan negara hukum Indonesia memiliki ciri-ciri khas Indonesia. Salah satu ciri pokok dalam negara hukum pancasila adanya jaminan terhadap kebebasan beragama sebagai pengakuan terhadapa HAM. Tetapi kebebasan yang dimaksud merupakan kebebasan dalam arti positif, yang mana tidak ada tempat bagi ateisme atau propaganda anti agama di bumi Indonesia. Ciri-ciri negara hukum pancasila lainnya yaitu: hubungan yang erat antara agama dan negara, bertumpu kepada kebebasan beraga dalam arti positif, ateisme tidak dibenarkan, komunisme dilarang, asas kekeluargaan dan kerukunan.

Setiap negara hukum tentunya memiliki ciri adanya perlindungan terhadap hak asasi manusia. Sebagai contoh perlindungan HAM di beberapa negara hukum: 


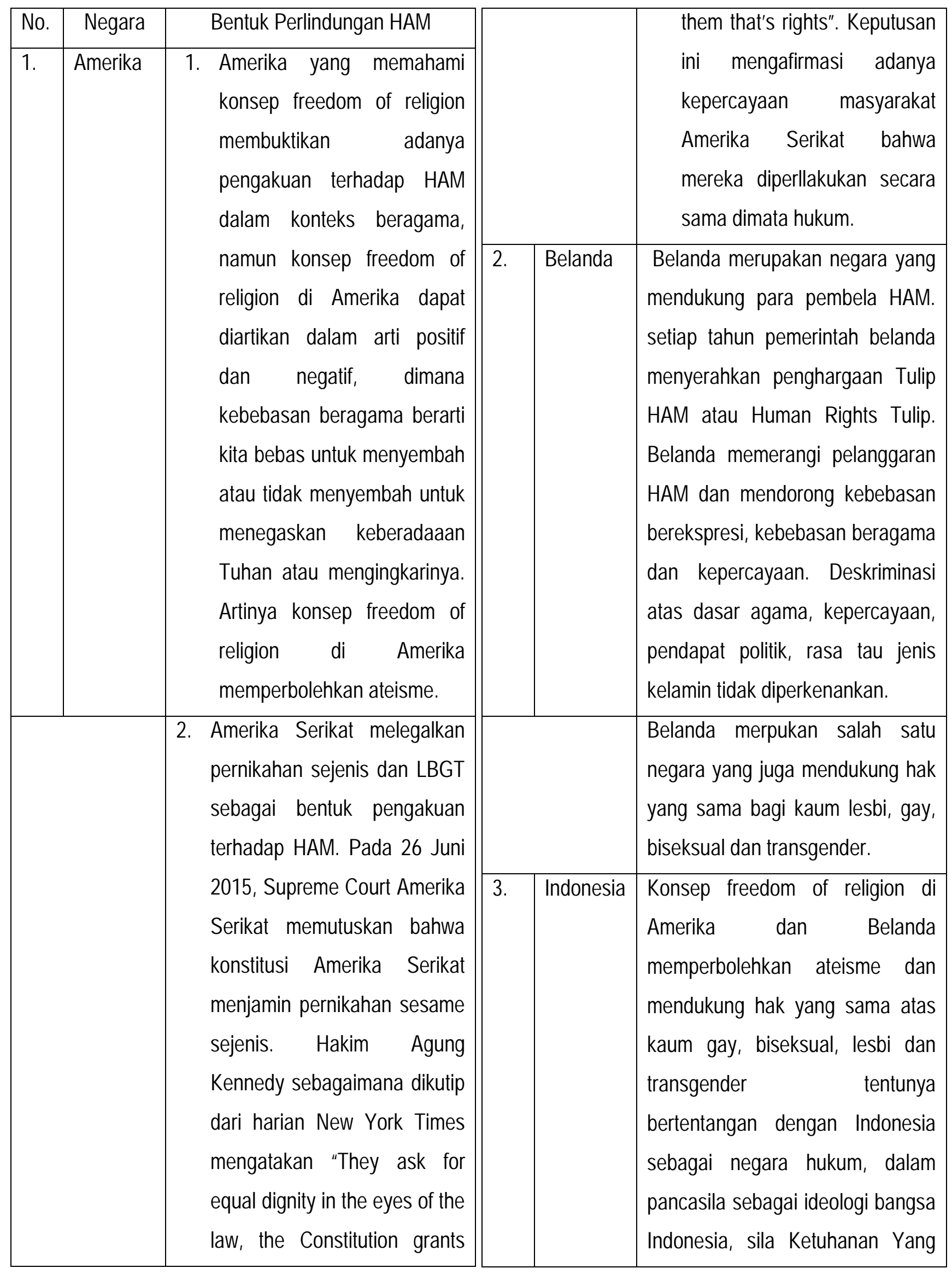




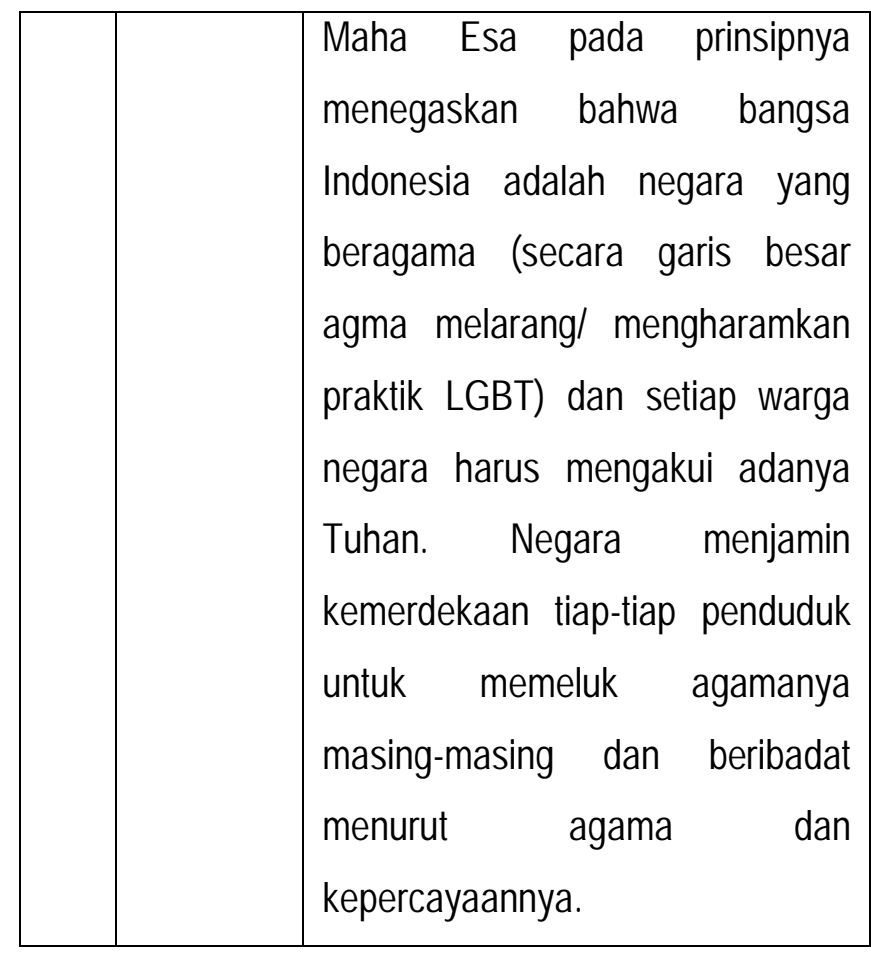

2. Konsepsi Negara Demokrasi Pancasila Dalam Kaitannya dengan HAM

Kata "Demokrasi" berasal dari dua kata, yaitu "Demos" Demos yang berarti rakyat dan "Cratos/ Cratein" yang berarti pemerintahan, sehingga dapat diartikan sebagai pemerintahan yang berasal rakyat, atau yang lebih kita kenal sebagai pemerintahan dari rakyat, oleh rakyat dan untuk rakyat (Jailani, 2015). Secara etimologis dalam bahasa yunani kuno demokrasi dapat diartikan sebagai kekuatan atau aturan rakyat (Fukuyama, dkk, 2010).

Negara demokrasi yang menganut bentuk atau mekanisme sistem pemerintahan dengan mewujudkan kedaulatan rakyat atas negara untuk dijalankan oleh pemerintah negara tersebut. Sehingga, isu mengenai demokrasi akan selalu berhubungan dengan isu mengenai hak asasi manusia. Perjuangan menegakkan demokrasi merupakan salah satu upaya umat manusia dalam rangka menjamin dan melindungi hak asisnya (Rosana, 2016).

Bagi bangsa Indonesia sendiri, demokrasi telah menjadi pilihan sejak para pendiri bangsa mempersiapkan dasar-dasar Indonesia merdeka. Demikian pula halnya dengan perlindungan dan penghormatan HAM yang telah diakui dalam UndangUndang Dasar Republik Indonesia Tahun 1945 sebelum perubahan. Namun, tak selamanya negara yang demokrasi menjamin tegaknya HAM. Janedjri M. Gaffar (2012) menyebutkan Demokrasi dan HAM bagaikan dua sisi mata uang yang tidak bisa dipisahkan. Perlindungan HAM adalah tujuan sekaligus prasyarat bagi berjalannya demokrasi. Sebaliknya, kegagalan perlindungan dan penghormatan HAM akan menjadi ancaman bagi demokrasi. Pernyataan dari Janedjri M. Gaffar dapat dibenarkan dengan melihat fakta pelaksanaan demokrasi dan HAM pada masa orde baru.

Praktik kehidupan demokratis, sebagaimana banyak terjadi di negara-negara berkembang, termasuk Indonesia sering terkecoh pada format politik yang kelihatannya demokratis, tetapi dalam praktiknya otoriter sebagaimana terjadi pada masa orde baru.

Akibat inkonsistensi dalam sikap dan pemikiran dalam menegakkan nilai-nilai dasar demokrasi, pada akhirnya orde baru terseret dalam praktik-praktik pemerintahan pragmatis dan otoriter dan hukum ditundukkan untuk mengabdi kepada sistem kekuasaan represif (Huda, 2014). 
Selama Orde Baru, HAM sipil dan politik banyak dilanggar dengan alasan untuk menjaga stabilitas politik demi kelancaran pembangunan ekonomi. Berikut beberapa bentuk pelanggaran HAM pada masa orde baru yang dikutip dari http://nasional.kompas.com /read2016/05/25/07220041/Kontras.Paparkan.10.Kas us.Pelanggaran.HAM.yang.DidugaMelibatkan.Soehar to?page=all

\begin{tabular}{|c|c|c|c|c|c|}
\hline \multirow{2}{*}{\multicolumn{3}{|c|}{$\begin{array}{l}\text { Selama Orde Baru, HAM sipil dan politik } \\
\text { banyak dilanggar dengan alasan untuk menjaga } \\
\text { stabilitas politik demi kelancaran pembangunan } \\
\text { ekonomi. Berikut beberapa bentuk pelanggaran HAM }\end{array}$}} & & & $\begin{array}{l}\text { "Indonesia-Extrajudicial } \\
\text { Executions of Suspected } \\
\text { Criminals"). }\end{array}$ \\
\hline & & & 3. & & Dalam peristiwa Tanjung Priok ini \\
\hline & & & & & \\
\hline & sional.komp & & & & menggunakan KOPKAMTIB \\
\hline & $16 / 05 / 25 / 07$ & 20041/Kontras.Paparkan.10.Kas & & & sebagai instrument penting \\
\hline & $\begin{array}{l}\text { ggaran. } \mathrm{H} \\
\text { =all }\end{array}$ & 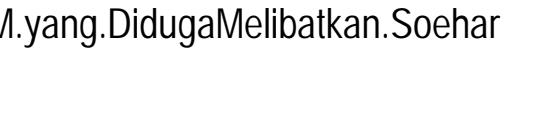 & & & $\begin{array}{l}\text { mendukung dan melindugi } \\
\text { kebijakan politiknya, selain itu }\end{array}$ \\
\hline No. & & Kasus & & & Soeharto juga selaku panglima \\
\hline 1. & $\begin{array}{l}\text { Kasus } \\
\text { Pulau Buru } \\
\text { 1965-1966 }\end{array}$ & $\begin{array}{l}\text { Terjadinya pembunuhan, } \\
\text { penangkapan penahanan massal } \\
\text { dan pembuangan ke pulau Buru } \\
\text { (laporan TIM Pengkajian } \\
\text { Pelanggaran HAM Soeharto, } \\
\text { KOmnas HAM 2003). }\end{array}$ & & & $\begin{array}{l}\text { tertinggi telah mengeluarkan } \\
\text { sikap, pernyataan dan kebijakan } \\
\text { yang bersifat represif untuk } \\
\text { mengeliminasi berbagai respon } \\
\text { masyarakatt terhadap kebijakan } \\
\text { asas tunggal Pancasila yang }\end{array}$ \\
\hline 2. & $\begin{array}{l}\text { Penembak } \\
\text { an } \\
\text { Misterius } \\
\text { 1981-1985 }\end{array}$ & $\begin{array}{l}\text { Hukuman Mati, terhadap } \\
\text { residivis, bromocorah, gali, } \\
\text { preman tanpa melalui } \\
\text { pengadilan. } \\
\text { mengungkapkan bahwa pelaku } \\
\text { criminal harus dihukum dengan } \\
\text { cara yang sama saat ia } \\
\text { memperlakukan korbannya. }\end{array}$ & & & $\begin{array}{l}\text { dikeluarkan ole horde baru. } \\
\text { dalam perisstiwa tanjung priok } \\
\text { 1984, sekitar lebih } 24 \text { orang } \\
\text { meninggal, } 36 \text { luka berat, } 19 \text { luka } \\
\text { ringan, ("Laporan } 5 \text { Sub Tim } \\
\text { Kajian, Tim Pengkajian } \\
\text { Pelanggaran HAM Soeharto", } \\
\text { Komnas HAM, 2003). }\end{array}$ \\
\hline & & $\begin{array}{l}\text { Amnesty Internasional dalam } \\
\text { laporannya memcatat korban } \\
\text { jiwa karena kebijakan tersebut } \\
\text { mencapai kurang lebih sekitar } \\
\text { lima ribu orang yang tersebar di } \\
\text { wilayah Jawa Timur, Jawa } \\
\text { Tengah, dan bandung (Amnesty } \\
\text { Internasional, } 31 \text { Oktober 1983, }\end{array}$ & 4. & $\begin{array}{l}\text { Talangsari } \\
\text { 1984-1987 }\end{array}$ & $\begin{array}{l}\text { Kebijakan represif yang dinilai } \\
\text { kontras diambil Soeharto } \\
\text { terhadap kelompok-kelompok } \\
\text { Islam yang dianggap ekstrem } \\
\text { juga mengakibatkan meletusnya } \\
\text { peristiwa Talangsari 1984-1987 } \\
\text { dan mengakibatkan korban } \\
\text { sebanyak } 130 \text { orang meninggal, }\end{array}$ \\
\hline
\end{tabular}




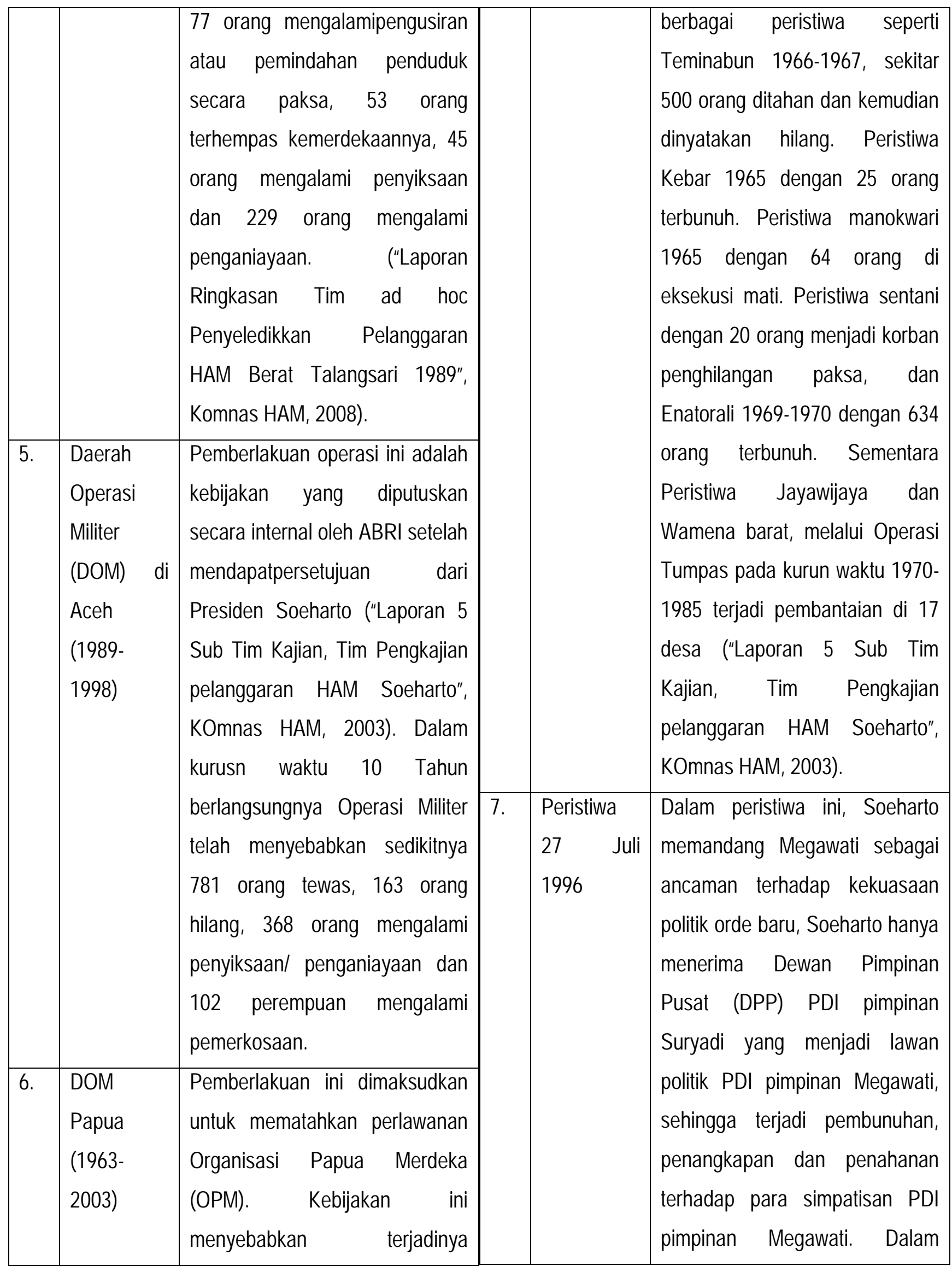




\begin{tabular}{|l|l|}
\hline peristiwa in, 11 orang meninggal, \\
149 lika-luka, 23 orang hilang, \\
124 orang ditahan.
\end{tabular}

Disamping pelanggaran HAM diatas, Korupsi, Kolusi dan Nepotisme juga merajalela, penyalahgunaan kekuasaan meluas, hukum merupakan subordinasi dari kekuasaan politik, dan campur tangan eksekutif terhadap kekuasaan kehakiman sudah menjadi cerita biasa. Padahal jika dilihat kembali, demokrasi yang diterapkan oleh pemerintah orde baru merupakan demokrasi pancasila yang mana inti dari konsep demokrasi pancasila adalah demokrasi kedaulatan rakyat yang dijiwai dan diintegrasikan dengan sila-sila lainnya (Sudrajat, 2016), serta menegakkan kembali asas negara hukum agar dirasakan oleh seluruh warga negara, hak asasi manusia baik secara kolektif maupun aspek perseorangan dijaman dan penyalahgunaan kekuasaan dapat dihindarkan secara institusional.

Derap reformasi yang mengawali lengsernya orde baru pada awal tahun 1998 pada dasarnya, merupakan gerak kesinambungan yang merefleksikan komitmen bangsa Indonesia yang secara rasional dan sistematis bertekad untuk mengaktualitaskan nilai-nilai dasar demokrasi. Setelah rezim demokrasi pancasila runtuh, penerapan demokrasi pancasila tetap dilakukan dalam tata pemerintahan di Indonesia. Demokrasi pancasila merupakan demokrasi konstitusional, sebagaimana dinyatakan dalam Pasal 1 ayat (2)

Undang-Undang Dasar Republik Indonesia Tahun 1945.
Selanjutnya, Demokrasi pancasila memiliki beberapa
prinsip yang diantaranya: Pertama, Persamaan bagi seluruh rakyat Indonesia, dimaksudkkan bahwa hak dan kewajiban yang dimiliki rakyat Indonesia sama dan sejajar. Kedua, Prinsip keseimbangan antara hak dan kewajiban, maksudnya negara menerima hak yang dimilikinya, namun juga harus diimbangi dengan kewajibannya terhadap warga negara. Ketiga, mewujudkan rasa keadilan sosial untuk semua warga negara. Keempat, pelaksanaan kebebasan yang bertanggung jawab secara moral kepada Tuhan Yang Maha Esa, diri sendiri dan orang lain. Keempat prinsip tersebut tidak terlepas dari penghormatan dan pengakuan HAM dalam konsep negara demokrasi pancasila.

Selanjutnya, dalam hubungannya dengan reformasi hukum dan kerangka aspek dasar demokrasi, pemerintah harus secara sistematis menerapkan reformasi yang didasarkan kepada elemen-elemen konsep sistem hukum, yaitu (1) struktur hukum; (2) substansi hukum; (3) budaya hukum. Friedmen menegaskan, bagaimanapun baiknya norma hukum, suatu Undang-Undang tanpa didukung penegak hukum yang handal dan dipercaya, hukum tidak akan efektif mencapai tujuannya. Hukum dengan norma yang baik dan didukung dengan aparat penegak hukum yang handal dan dipercaya juga akan kurang efektif tanpa didukung budaya masyarakat yang bersangkutan (Huda, 2014). 
Jurnal Pembangunan Hukum Indonesia

Volume 1, Nomor 1, Tahun 2019
Program Studi Magister Ilmu Hukum Fakultas Hukum Universitas Diponegoro
Mengingat masih banyaknya bentuk pelanggaran HAM di Indonesia perlu dilihat bagaimana kedudukan HAM dalam sistem hukum Indonesia. Kedudukan tersebut akan dilihat berdasarkan teori sistem hukum yang dikemukakan oleh Lawrence M. Friedman:

\section{Substansi Hukum}

Substansi tersusun dari peraturan-peraturan dan ketentuan mengenai bagaimana institusi-institusi itu harus berperilaku. H.L.A Hart berpendapat bahwa ciri khas suatu sistem hukum adalah kumpulan ganda dari peraturanperaturan. Suau sistem hukum adalah kesatuan dari "peraturan-peraturan primer" dan "peraturan-peraturan sekunder". Baik peraturan primer maupaun peraturan sekunder adalah samasama output dari sebuah sistem hukum (Friedman, 2011).

Sudah menjadi ketentuan ketatanegaraan sebagai suatu kesepakatan serta doktrin kenegaraan, bahwa pancasila adalah pandangan hidup, ideologi bangsa Indonesia serta "sumber segala sumber hukum" Indonesia. Dalam konteks pancasila sebagai segala sumber hukum, kita uji dengan teori pakar hukum kenegaraan Hans Kelsen yang lazim dianalogikan dengan Teori Tangga atau Stuffen Theory. Berdasararkan teori Stuffen Theory maka kedudukan pancasila berada pada tangga tertinggi. Hal ini berarti bahwa Pancasila harus diletakkan sebagai kaidah dasar, groundnorms atau sumber segala sumber hukum yang menjadi dasar bagi berlakunya Undang-Undang Dasar Republik Indonesia Tahun 1945 (Bisri, 2014).
Pancasila sebagai groundnorms telah mengandung pengakuan HAM, hal ini dapat dilihat dari. Pertama, sila ketuhanan secara tersirat memberikan kewajiban bagi negara untuk menjamin kemerdekaan tiap-tiap penduduk untuk memeluk agamnya masing-masing dan beribadat menurut agama dan kepercayaannya itu. Kedua, Kemanusian yang adil dan beradab, sila kedua ini kemudian diejahwantahkan dalam Pasal-Pasal Undang-Undang Dasar Republik Indonesia Tahun 1945 yang selaras dengan prinsip HAM. Nilai nilai yang terkandung didalam pengejahwantahan tersebut diantaranya; (a) pemeliharaan, pengayoman terhadap jiwa atau diri ini mulai dari yang lahir sampai yang bathin; (b) perlindungan terhadapkeberlangsungan kehidupan individu, perlindungan diri pribadi, keluarga, kehormatan dan martabatnya, Ketiga, Keadilan sosial bagi seluruh rakyat Indonesia, secara umum keadilan sosial bagi seluruh rakyat Indonesia berarti bahwa setiap orang Indonesia mendapat perlakuan yang adil dalam bidang hukum, politik, sosial, ekonomi dan kebudayaan (Pimpinan MPR dan Tim Kerja Sosialisasi MPR Periode 2009-2014, 2014).

Disamping pancasila, Undang-Undang Dasar Republik Indonesia Tahun 1945 juga telah memuat aturan mengenai HAM baik sebelum amandemen maupaun pasca amandemen. Perbedaanya, pengaturan HAM dalam Undang-Undang Dasar pasca amandemen lebih luas pengaturannya, yang awalnya hanya 5 Pasal (hak katas pekerjaan dan penghidupan yang layak bagi kemanusiaan, kemerdekaan berserikat dan berkumpul serta 
mengeluarkan pikiran dengan lisan maupaun tulisan, jaminan kemerdekaan beragama dan berkepercayaan, serta ha katas pengajaran, ha katas akses sumber daya alam) menjadi setidaknya 17 Pasal (dengan 38 substansi hak-hak yang beragam) yang terkait dengan HAM (Wiratraman, 2007). Menurut Lindsey hasil amandemen Undang-Undang Dasar Republik Indonesia Tahun 1945 dibidang HAM paling impresif karena mencakup daftar HAM yang luas, melebihi konstitusi negara-negara maju, serta mandemen tersebut lebih mampu menghadirkan asas konstitusionalisme dibandingkan sebelumnya (Kurnia, 2015).

Universal Declaration of Human Right (UDHR) atau Deklarasi Universal Hak Asasi Manusia (DUHAM) yang lahir pada 10 Desember 1945 di Paris merupakan respon dari mayoritas masyarakat dunia bahwa manusia dilahirkan dengan kebebasan dan memiliki kesamaan derajat serta dihadapan hukum.

Pengaturan mengenai HAM yang ada, baik dalam Pancasila maupun Undang-Undang Dasar Republik Indonesia Tahun 1945 kemudian di formalkan kedalam Undang-Undang yaitu Undang-Undang Nomor 39 Tahun 1999 Tentang Hak Asasi Manusia dan Undang-Undang Nomor 26 Tahun 2000 Tentang Pengadilan Hak Asasi Manusia dan peraturan perundang-undangan lainnya yang mengatur mengenai HAM seperti ratifikasi Konvensi Hak-Hak Sipil dan Politik melalui Undang-Undang No. 12 Tahun 2005, ratifikasi konvensi tentang hak-hak politik perempuan melalui Undang-Undang No. 68
Tahun 1958, ratifikasi International Convention On The Elimination Of All Forms Of Racial Discrimination 1965 melalui Undang-Undang No. 29 Tahun 1999, ratifikiasi kovenan internasional tentang Hak-Hak EKOSOB melaui Undang-Undang No. 11 Tahun 2005.

\section{Struktur Hukum}

Struktur hukum adalah komponen struktural atau organ yang bergerak di dalam suatu mekanisme, baik dalam membuat peraturan, maupun dalam menerapkan atau melaksanakan peraturan (Purba, 2017).

Salah satu perubahan yang dilakukan pasca amandemen Undang-Undang Dasar Republik Indonesia Tahun 1945 ialah semakin besarnya perhatian masyararakat dan pemegang kekuasaan untuk menegaskan dan meneggakkan HAM. Implikasi dari amandemen Undang-Undang Dasar Republik Indonesia Tahun 1945 juga telah melahirkan lembaga-lembaga yang bersifat Ad Hoc yang dibentuk dengan UndangUndang dan lembaga-lembaga peradilan yang berperan signifikan dalam penegakan HAM di Indonesia. Setidaknya telah ada dua lembaga yang berperan dalam penegakan HAM di Indonesia, yaitu: Pertama, lembaga negara penegak HAM yang terdiri dari Komnas HAM, Komisi Perlindungan Anak Indonesia (KPAI), Komnas Perempuan, Komisi Kebenaran dan Rekonsiliasi. Kedua, lembaga peradilan sebagai penegak HAM yang terdiri dari Pengadilan HAM dan Mahkama Konstitusi (Putra, 2015).

\section{Kultur Hukum}


Kultur Hukum/ Budaya hukum, dalam pengertian Friedman (1998), adalah "nilai, pendapat, sikap dan keyakinan tentang hukum" (Ginsburg, 2010). Sedangkan Menurut Esmi Warassih menyebutkan:

Kultur/ budaya hukum adalah nilai-nilai dan sikap-sikap yang merupakan pengikat sistem itu, serta menentukan tempat sistem itu ditengah-tengah budaya bangsa sebagai keseluruhan (Warassih, 2016).

Pemahaman HAM sebagai tatanan nilai, norma, sikap yang hidup dalam masyarakat dan acuan bertindak pada dasarnya berlangsung sudah cukup lama baik sebelum kemerdekaan maupun setelah kemerdekaan.

Masyarakat Indonesia yang berkembang sejak masih sangat sederhana sampai modern, pada dasarnya merupakan masyarakat kekeluargaan. Masyarakat kekeluargaan telah mengenal pranata sosial yang menyangkut hak dan kewajiban warga masyarakat yang terdiri atas pranata religius yang mengakui bahwa manusia adalah ciptaan Tuhan Yang Maha Esa dengan segala hak dan kewajiban, pranata kekeluargaan sebagai wadah manusia hidup manusia hidup untuk mengembangkan keturunan dalam menjaga kelangsungan keberadaanya, pranata ekonomi yang merupakan upaya manusia untuk meningkatkan kesejahteraan, pranata pendidikan dan pengajaran untuk mengembangkan kecerdasan dan kepribadian informasi dan komunikasi untuk memperluas wawasan dan keterbukaan. Bangsa Indonesia menyadari dan mengakui bahwa setiap individu adalah bagian dari masyarakat dan sebaliknya masyarakat terdiri dari individu-individu yang mempunyai Hak Asasi serta hidup didalam lingkungan yang merupakan sumber daya bagi kehidupannya (Neta, 2013). Oleh karena itu, kesadaran akan pentingnya perlindungan dan penegakan HAM tidak hanya ditegakkan oleh pemerintah melalui lembaga yang dibentuk oleh pemerintah, melainkan melalui LSM dan/atau NGO yang bergerak dalam bidang HAM yang didirikan oleh masyarakat maupun kelompok orang sebagai bagian kesadaran akan pentingnya perlindungan dan penegakan hukum di Indonesia. LSM dan/atau NGO tersebut diantaranya Yayasan Lembaga Bantuan Hukum Indoneisa (YLBHI), Lembaga Bantuan Hukum (LBH), Biro Konsultasi dan Bantuan Hukum (BKBH) Perguruan Tinggi dan Komisi Orang Hilang dan Korban Tindak Kekerasan (KONTRAS).

\section{KESIMPULAN}

1. Indonesia adalah negara hukum termuat dalam Pasal 1 ayat (3) Undang-Undang Dasar Republik Indonesia Tahun 1945. Meskipun dalam penjelasan Undang-Undang Dasar Republik Indonesia Tahun 1945 digunakan istilah rechtsstaat, namun yang dianut oleh negara Indonesia bukanlah konsep rechtsstaat maupun rule of law. Alasannya, Konsep negara hukum sebenarnya bukanlah konsep yang lahir dari kebudayaan Indonesia melainkan dari dunia barat. Sebagai negara yang berlandaskan pancasila konsep negara hukum Indonesia merupakan konsep negara hukum pancasila. Berbicara mengenai perlindungan HAM dalam 
konsep negara hukum, baik rechtsstaat, rule of law maupun negara hukum pancasila samasama mengakui adanya jaminan dan perlindungan terhadap HAM. Dalam konteks negara hukum pancasila HAM telah termuat di dalam pancasila itu sendiri. Dalam sila pertama misalnya. Ketuhanan Yang Maha Esa, dalam sila ini pada prinsipnya telah menegaskan adanya kebebasan bagi setiap warga negara untuk memeluk agamanya masing-masing dan beribadah sesuai dengan agama dan kepercayaannya, namun tetap dalam arti yang positif.

2. Perjuangan menegakkan demokrasi merupakan salah satu upaya umat manusia dalam rangka menjamin dan melindungi hak asasinya. Di Indonesia, sebagai sebagai negara demokrasi pancasila, perlindungan HAM menjadi tujuan sekaligus prasyarat bagi berjalannya demokrasi. Dimana prinsip persamaan bagi seluruh rakyat Indonesia, keseimbangan hak dan kewajiban, kebebasan yang bertanggung jawab dan memujudkan keadailan bagi seluruh rakyat merupakan bentuk pengakuan dan penghormatan terhadap HAM dalam konsep negara demokrasi pancasila.

\section{DAFTAR PUSTAKA :}

\section{Buku:}

Assiddiqie, J. (2012), Hukum Tata Negara dan PilarPilar Demokrasi, Ed.2, Cet.2, Jakarta: Sinar Grafika.
Bisri, I. (2014), Sistem Hukum Indonesia PrinsipPrinsip dan Implementasi Hukum di Indonesia, Ed.1, Cet.9, Jakarta: Rajawali Pers.

Friedman, Lawrence. M. (2011), Sistem Hukum Perspektif IImu Sosial, Cet. IV. Terjemahan oleh M. Khozim, Bandung: Nusa Media.

Gaffar, Janedjri. M. (2012), Demokrasi Konstitusional Praktik Ketatanegaraan Indonesia Setelah Perubahan UUD 1945, Cet-1, Jakarta: Konstitusi Press.

Hamidi, J. et.all: (2012), Teori Hukum Tata Negara : A Turning Point of The State, Jakarta; Salemba Humanika.

Huda, N. (2014), Hukum Tata Negara Indonesia, EdRevisi, Ce-9, Jakarta: Rajawali Pers.

Kiemas, T. (2013), Empat Pilar Kehidupan Berbangsa dan Bernegara Sebagai Sumber Moralitas dan Hukum Nasional, Jakarta: Penerbit Universitas Trisakti.

Kurnia, Titon. S. (2015), Interpretasi Hak-Hak Asasi Manusia Oleh Mahkama Konstitusi Republik Indonesia, Bandung: CV. Mandar Maju.

Pimpinan MPR dan Tim Kerja Sosialisasi MPR Periode 2009-2014, 2014, Empat Pilar Kehidupan Berbangsa dan Bernegara, Jakarta: Sekretariat Jendral MPR RI.

Qamar, N. (2010), Negara Hukum atau Negara Undang-Undang, Cet.1, Makassar: Pustaka Refleksi Books.

Qamar, M. (2014), Pengantar Ilmu Hukum Tata Negara, Ed.1-6, Jakarta: Rajawali Pers. 
Jurnal Pembangunan Hukum Indonesia

Volume 1, Nomor 1, Tahun 2019
Program Studi Magister Ilmu Hukum Fakultas Hukum Universitas Diponegoro
Rahardjo, S. (2009), Negara Hukum Yang Membahagiakan Rakyatnya, Yogyakarta: Genta Publishing.

Soehino, (2011), Hukum Tata Negara Bunga Rampai Hukum, Politik, Demokrasi, dan Pemerintahan di Negara Republik Indonesia, Cet-1, Yogyakarta: BPFE.

Warassih, E. (2016), Pranata Hukum Sebuah Telaah

Sosiologis, Cet.4, Semarang: Penerbit Pustaka Magister.

\section{J urnal:}

Rosana, E. (2016), Negara Demokrasi dan Hak Asasi Manusia, J urnal TAPIs, Vol.12, (No.1). pp 3852.

Fukuyama, F. dkk, (2010), Democracy's Past and Future, J ournal of Democracy, Vol 21,(No. 1). pp 1-5

Ginsburg. T. (2010). Lawrence M. Friedman's Comparative Law, Public Law and Legal Theory Working Papers, University of Chicago Law School. pp 1-16.

Jailani. (2015), Sistem Demokrasi Di Indonesia Ditinjau Dari Sudut Hukum Kekatatnegaraan, J urnal Inovatif, Vol. III, (No. I). pp 134-147.

Khairazi, F. (2015), Implementasi Demokrasi dan Hak Asasi Manusia di indonesia, Jurnal Inovatif, Vol. VIII, (No.1), pp 72-94.

Marbun, R. (2014), Grand Design Politik Hukum Pidana dan Sistem Hukum Pidana Indonesia Berdasarkan Pancasila dan Undang-Undang Dasar Negara Republik Indonesia 1945, J urnal
Padjadjaran J urnal IImu Hukum, Vol. 1, (No. 3). pp 558-577.

Neta, Y. (2011), Demokrasi dan Hak Asasi Manusia Dalam Konsep Negara Hukum (Qua Vadis Demokrasi dan HAM di Indonesia di Era Globalisasi. (pp 1-9). Lampung: UNILA.

Neta, Y. (2013), Partisipasi Masyarakat Terhadap Penegakan Hak Asasi Manusia Di Negara Demokrasi Indonesia, J urnal Monograf, Vol.1. pp 1-11.

Purba, Iman Pasu Marganda H. (2017), Penguatan Budaya Hukum Masyarakat Untuk Menghasilkan Kewarganegaraan Transformatif, J urnal Civics, Vol. 14, (No.2). pp 146-153.

Putra, Muhammad A. (2015), Eksistensi Lembaga Negara Dalam Penegakan Hak Asasi Manusia di Indonesia, Jurnal Fiat Justisia J urnal IImu Hukum, Vol. 9, (No. 3), pp 256-292.

Ridlwan, Z. (2012), Negera Hukum Indonesia Kebalikan Nachtwachterstaat, Jurnal Fiat J ustisia J urnal IImu Hukum, Vol 5, (No.2), pp 141-152

Simamora. J, (2014), Tafsir Makna Negara Hukum Dalam Persfektif Undang-Undang Dasar Negara Republik IndonesiaTahun 1945, J urnal Dinamika Hukum, Vol. 14, (No. 3). pp 548-561 Sudrajat, A. (2016), Demokrasi Pancasila Dalam Persfektif Sejarah, Vol 8, (No. 1). pp 1-17.

Wijaya, Made H. (2015), Karakteristik Konsep Negara Hukum Pancasila, Jurnal Advokasi Vol. 5, (No. 2). pp 199-213. 
Jurnal Pembangunan Hukum Indonesia

Volume 1, Nomor 1, Tahun 2019
Program Studi Magister Ilmu Hukum Fakultas Hukum Universitas Diponegoro

Wiratraman, R Herlambang P. (2007), Hak-Hak Konstitusi Warga Negara Setelah Amandemen UUD 1945: Konsep, Pengaturan dan Dinamika Implementasiny, J urnal Hukum panta Rei, Vol. 1, (No. 1). pp 1-19.

Yansyah, R. \& Rahayu. (2018), Globalisasi Lesbian, Gay, Biseksual, Dan Transgender (LGBT): Persfektif HAM dan Agama Dalam Lingkup Hukum Di Indonesia, Law Reform, Vol. 14, (No. 1), pp 132-146.

Yuliartha. I. G. (2009), Lembaga Praperadilan Dalam Persfektif Kini dan Masa Mendatang Dalam Hubungannya Dengan Hak Asasi Manusia, J urnal Law Reform, Vol.5, (No.1). pp 1-24.

\section{Website:}

Hutapea, Rita U. (2016). Pelanggaran HAM AMerika

Dikritik dalam Laporan Human Right Watch.

Retrieved from

https://news.detik.com/internasional/d-

3132663/pelanggaran-ham-amerika-dikritik-

dalam-laporan-human-rights-watch

Tribun Jogja.com. (2013). Indonesia Peringkat Ke-30

Negara HAM Terburuk di Dunia. Retrieved

from http://jogja.tribunnews.com/2013/12/05/

indonesia-peringkat-ke-30-negara-ham-

terburuk-di-dunia.

Erdianto, K. (2018). Konflik dan Pelanggaran HAM ;

Catatan Kelam 20 Tahun Reformasi. Retrieved from http://nasional.kompas.com/jeo/konflik-danpelanggaran- ham-catatan-kelam-20-tahunreformasi). 